\title{
METABOLIC RATES OF THE ANTARCTIC AMPHIPOD Gondogeneia antarctica AT DIFFERENT TEMPERATURES AND SALINITIES
}

\author{
Vicente Gomes ${ }^{1, *}$, Maria José de Arruda Campos Rocha Passos ${ }^{1}$, Arthur José da Silva Rocha ${ }^{l}$, \\ Thais da Cruz Alves dos Santos ${ }^{2}$, Alex Sander Dias Machado ${ }^{3}$ and Phan Van Ngan ${ }^{1}$ \\ Instituto Oceanográfico da Universidade de São Paulo \\ (Praça do Oceanográfico, 191, 05508-120 São Paulo, SP, Brasil) \\ Universidade Monte Serrat - UNIMONTE \\ (Rua Comendador Martins, 52, 11015-530 Santos, SP, Brasil) \\ Faculdades Unidas do Norte de Minas - FUNORTE \\ (Avenida Osmane Barbosa, 11111, 39404-006 Montes Claros, MG, Brasil) \\ *Corresponding author: vicgomes@usp.br
}

\begin{abstract}
A B S T R A C T
Changes in environmental factors may deeply affect the energy budget of Antarctic organisms as many of them are stenothermal and/or stenohaline ectotherms. In this context, the aim of this study is to contribute to knowledge on variations in the energy demand of the Antarctic amphipod, Gondogeneia antarctica as a function of temperature and salinity. Experiments were held at the Brazilian Antarctic Station "Comandante Ferraz", under controlled conditions. Animals collected at Admiralty Bay were acclimated to temperatures of $0^{\circ} \mathrm{C} ; 2.5^{\circ} \mathrm{C}$ and $5^{\circ} \mathrm{C}$ and to salinities of 35,30 and 25 . Thirty measurements were made for each of the nine combinations of the three temperatures and three salinities, totalling 270 measurements. Metabolic rates were assessed by oxygen consumption and total nitrogenous ammonia excretion, in sealed respirometers. When acclimated to salinities 30 or 35 , metabolic rates at $0^{\circ} \mathrm{C}$ and $2.5^{\circ} \mathrm{C}$ were very similar indicating a possible mechanism of metabolic compensation for temperature. At $5.0^{\circ} \mathrm{C}$, however, metabolic rates were always higher. Lower salinities enhanced the effects of temperature on metabolism and ammonia excretion rates. The physiological adaptations of individuals of $G$. antarctica suggest adaptive mechanisms for energy saving, adjusted to an environment with stable conditions of temperature and salinity. Little is known about the joint effects of salinity and temperature and this study is an important contribution to the understanding of the mechanism of polar organisms in their adaptation to both factors.
\end{abstract}

\section{RESUMO}

Alterações ambientais podem modificar a alocação de energia dos organismos, principalmente dos ectotermos estenotérmicos e/ou estenohalinos. Nesse contexto, este trabalho contribui com o conhecimento da demanda de energia do anfípode antártico Gondogeneia antarctica em função da temperatura e da salinidade. Experimentos foram realizados na Estação Antártica Brasileira "Comandante Ferraz", em condições laboratoriais controladas. Animais coletados na Baía do Almirantado foram aclimatados a temperaturas de $0^{\circ} \mathrm{C} ; 2.5^{\circ} \mathrm{C}$ e $5^{\circ} \mathrm{C}$ e salinidades de 35,30 and 25 . Foram realizadas trinta medições para cada uma das nove combinações das três temperaturas com as três salinidades, totalizando 270 medições. As taxas metabólicas foram estimadas por meio do consumo de oxigênio e excreção de amônia, em câmaras respirométricas seladas. Quando aclimatados a salinidades 30 ou 35 , as taxas metabólicas a $0^{\circ} \mathrm{C}$ e $2.5^{\circ} \mathrm{C}$ foram semelhantes indicando possível mecanismo de compensação térmica, nessa faixa de variação dos fatores. A $5.0^{\circ} \mathrm{C}$, no entanto, as taxas metabólicas foram sempre mais elevadas. Baixas salinidades potencializaram os efeitos da temperatura no consumo de oxigênio e na excreção de produtos nitrogenados. Os resultados estão relacionados a mecanismos adaptativos para economia de energia em indivíduos $G$. antarctica, ajustados a um ambiente que tem condições estáveis de temperatura e de salinidade. Pouco se sabe sobre os efeitos conjugados da salinidade e temperatura nos organismos e este trabalho é uma importante contribuição para esse conhecimento.

Descriptors: Antarctica, Amphipods, Metabolism, Temperature, Salinity. Descritores: Antártica, Anfípodes, Metabolismo, Temperatura, Salinidade. 


\section{INTRODUCTION}

The Antarctic marine ecosystem can be considered highly fragile in relation to changes in certain environmental factors. Light cycles, sea ice, and primary production in the water column are strikingly different between summer and winter, but sea water temperatures are stable, usually fluctuating between $-2^{\circ} \mathrm{C}$ and $+3^{\circ} \mathrm{C}$ all year long (EICKEN, 1992). Sea water temperatures have remained almost the same during millions of years and this has been an essential selective feature for the settlement of an Antarctic ectothermal fauna with a great number of stenothermal species (ARNTZ et al., 1994). Stable coldness associated with the seasonality of food production has been a driving force for the establishment of traits directed to energy saving, such as low metabolism, long lifespan with reduced growth rates and low fecundity, seasonal reproduction and delayed maturation (WHITE, 1984; HEMPEL, 1990).

Metabolic rates as a single parameter can be used to describe the energy demands of a living being, so studies on animals that usually have low metabolic rates, energy saving mechanisms and low resilience to environmental shifts can contribute to the understanding of climatic effects at the individual level. This knowledge can be assessed by measuring the metabolic oxygen consumption and nitrogen wastes of shallow water organisms at different temperatures while maintaining the usual salinity (35). Salinity, however, although generally stable, can be modified temporarily in coastal regions by melting ice (SZAFRANSKI; LIPSKI, 1982). When temperature is studied in conjunction with salinity variations, the importance of temperature changes can be even better understood and reveal important shifts in energy demand (ROCHA et al., 2001; ALLAN et al., 2006; FILIPPOV, 2006). In addition, laboratory investigations can also improve our comprehension of the homeostatic abilities to modulate processes according to the degree of temperature and salinity variations.

Antarctic shallow water and intertidal zones are occupied by a vagile fauna. Sessile animals are not present due to ice formation during winter. Vegetal detritus is a source of energy for an abundant fauna of small crustaceans, mainly amphipods, that are preyed upon by other invertebrates and fish. Individuals of Gondogeneia antarctica (CHEVREUX, 1906) are the most abundant amphipod in the shallow waters of Admiralty Bay (De BROYER; JAZDZEWSKI, 1993). They are very suitable as biological material for this kind of study for a number of reasons: they are highly abundant in the subtidal zone of west Antarctica and are of great importance in coastal food webs (RICHARDSON, 1975; DUARTE; MORENO, 1981; JAZDZEWSKI et al., 2001); they can be easily collected during low tides with a hand net; they are very resistant and feed well in captivity. Our research group selected them as bioindicator organisms for biomonitoring studies after a long series of trials with a great number of species, due to their sensibility and the constancy of their responses to variations in environmental factors (GOMES et al., 2009).

The main purpose of this study was to evaluate the effects of temperature and salinity on the energy demand of $G$. antarctica acclimated to different conditions of both parameters, through the variations in oxygen consumption and nitrogen excretion, to enhance the understanding of the metabolic adaptations of these organisms to the environment.

\section{Material And Methods}

This study was undertaken at the Brazilian Antarctic Station "Comandante Ferraz" located on the Martel inlet in Admiralty Bay, in southwestern King George Island. The coastal slope is steep and reaches a depth of $500 \mathrm{~m}$ in the central regions, like a fjord with a great U-shaped valley (RAKUSA-SUSZCZEWSKI, 1980; WEBER; MONTONE, 2006; MONTONE et al., 2013). During summer, at the surface, mean sea water salinity is 34 and temperature may range from $-0.2^{\circ} \mathrm{C}$ to $5.3^{\circ} \mathrm{C}$; at the bottom, mean salinity is 34.5 and temperature varies from $-0.4^{\circ} \mathrm{C}$ to $0.9^{\circ} \mathrm{C}$ (PRUSZAK, 1980; JAZDZESKI et al., 1986).

Specimens of $G$. antarctica were gently collected with a small hand net, during low tide, from among the sea-floor pebbles at a depth of 30 to $50 \mathrm{~cm}$. During the sampling period, the local temperature was between $0.5^{\circ} \mathrm{C}$ and $2.5^{\circ} \mathrm{C}$ and salinity between 34.5 and 35. Specimens were sorted and maintained for 10 days in tanks filled with 200 litres of sea water with salinity 35 and temperature between $1.0^{\circ} \mathrm{C}$ and $2.0^{\circ} \mathrm{C}$, renewed daily, and artificially aerated. They were daily fed ad libitum with the various algae of their natural diet, collected at the same locations as the amphipods themselves. After this resting period, the animals were transferred to smaller 50 litres tanks and the water in each was adjusted to the desired combination of salinity and temperature over a period of 24 hours. The animals were then acclimated for 5 days under their respective experimental conditions. The temperature was maintained constant using a thermostatized water bath. All the water used during maintenance periods and for the experiments was passed through a $1 \mu \mathrm{m}$ porosity pressure filter. The animals' mean weight was $0.057 \mathrm{~g}( \pm 0.011)$, they were adults but were not carrying siblings in the marsupium. Feeding was suspended 24 hours before measurements were taken. 
The following combinations of temperaturesalinity were used: $0^{\circ} \mathrm{C}-25 ; 0^{\circ} \mathrm{C}-30 ; 0^{\circ} \mathrm{C}-35 ; 2.5^{\circ} \mathrm{C}-$ $25 ; 2.5^{\circ} \mathrm{C}-30 ; 2.5^{\circ} \mathrm{C}-35 ; 5.0^{\circ} \mathrm{C}-25 ; 5.0^{\circ} \mathrm{C}-30 ; 5.0^{\circ} \mathrm{C}-$ 35 . The temperature and salinity of each of these combinations were selected because they fell within the expected range of variations of the local surface waters in any climatic change event, as explained above. Thirty individuals were used for each combination. Experiments were held during the austral summer, with a light period of 18 hours.

Oxygen consumption and ammonia excretion were measured in water samples from sealed neutral acrylic respirometric chambers of $30 \mathrm{ml}$ to $40 \mathrm{ml}$, depending on the size of the animal selected by observation only. One acclimated amphipod was gently introduced into one respirometric chamber and left for three hours with running water to diminish the stress due to handling. The water supply was then suspended and the chambers were sealed for a period that was experimentally established at 4 hours to prevent oxygen concentration at the end of the experiment from falling below $70 \%$ of the initial concentration. Animals could move freely inside the chambers but not swim extensively. The experimental system was covered to diminish stress. The respirometers were periodically observed to ensure that the animals were quiet for at least $90 \%$ of the period of observation. Data from stressed animals were not taken into consideration. To obtain at least 30 measurements, five spare sealed chambers with amphipods were always included in the experiments. As the amphipods were already acclimated just a few animals had to be discarded. Of the animals that showed satisfactory quietness, 30 were chosen at random to be used for the experiments.

Water samples were taken just before sealing and just after opening the respirometric chambers to determine dissolved oxygen and ammonia concentrations. Differences between these two measurements, related to water volume, animal volume and time were used to calculate consumption and excretion. All measurements were made during day time and no amphipod was used twice. Dissolved oxygen was determined by Winkler's method modified by Fox and Wingfield (1938) for small volumes of water. Ammonia content was determined by the method described by Koroleff (1970 apud Grasshoff et al., 1999). Animals were weighed at the end of the experiments with a precision of $0.0001 \mathrm{~g}$. Oxygen consumption was expressed as $\mu \mathrm{LO}_{2} / \mathrm{g}$.h and ammonia excretion as $\mu \mathrm{M}-\mathrm{N} / \mathrm{g}$.h. The means of oxygen consumption and ammonia excretion were calculated from measurements obtained from animals acclimated to each of the nine combinations of temperature and salinity.

Data were checked for normal distribution by the Shapiro-Wilks test and for variance homogeneity by the Levene test. To evaluate the differences between means, a two way ANOVA test followed by the Tukey test for multiple comparisons were employed $(\mathrm{p} \leq 0.05)$.

The ratio between oxygen consumed and nitrogen excreted $(\mathrm{O}: \mathrm{N})$ was calculated for each group of the 9 combinations of temperature and salinity, using the adjusted data (MAYZAUD, 1973; MAYZAUD; CONOVER, 1988). The O:N ratio gives an indication of the kind of substrate that is being used for catabolism in a particular condition.

\section{RESULTS}

The means $( \pm \mathrm{SD})$ of the oxygen consumption rates of $G$. antarctica as a function of temperature at different salinities (Fig. 1a) indicate that at salinity 25 , oxygen consumption increased significantly with increasing temperature. At this salinity, consumption increased $37 \%$ between $0.0^{\circ} \mathrm{C}$ and $2.5^{\circ} \mathrm{C}$ and $22 \%$ between $2.5^{\circ} \mathrm{C}$ and $5.0^{\circ} \mathrm{C}$.

At salinity 30 , the metabolic increase shows a different trend from that obtained at salinity 25 . Oxygen consumption increased only $9 \%$ between $0.0^{\circ} \mathrm{C}$ and $2.5^{\circ} \mathrm{C}$, but $52 \%$ between $2.5^{\circ} \mathrm{C}$ and $5.0^{\circ} \mathrm{C}$. Consumption at $0.0^{\circ} \mathrm{C}$ was not significantly different from that at $2.5^{\circ} \mathrm{C}$ but both of them were significantly different from that at $5.0^{\circ} \mathrm{C}$.

At salinity 35 the oxygen consumption trend was very similar to that obtained at salinity 30 ; consumption increased only $9 \%$ between $0.0^{\circ} \mathrm{C}$ and $2.5^{\circ} \mathrm{C}$; but, significantly distinct from the others, it was $53 \%$ higher between $2.5^{\circ} \mathrm{C}$ and $5.0^{\circ} \mathrm{C}$ The consumption at $0.0^{\circ} \mathrm{C}$ was not significantly different from that at $2.5^{\circ} \mathrm{C}$ but both of them were significantly different from that at $5.0^{\circ} \mathrm{C}$.

The means $( \pm \mathrm{SD})$ of oxygen consumption rates of amphipods as a function of salinities at different temperatures (Fig.1b) showed that at the three temperatures studied, oxygen consumption decreased with increasing salinity. At $0.0^{\circ} \mathrm{C}$ and at $5.0^{\circ} \mathrm{C}$, consumption diminished around $8 \%$ between salinities 25 and 30 ; at temperature $2.5^{\circ} \mathrm{C}$, consumption diminished $35 \%$ between salinities 25 and 30. At all temperatures, consumption diminished about $15 \%$ between salinities 30 and 35 .

The means $( \pm \mathrm{SD})$ of ammonia excretion rates of $G$. antarctica at different combinations of temperatures and salinities (Fig. 2a) indicate that at all salinities, excretion at $0.0^{\circ} \mathrm{C}$ and $2.5^{\circ} \mathrm{C}$ were not significantly different from each other but both of them were significantly different from that at $5.0^{\circ} \mathrm{C}$. When considering variations between $0.0^{\circ} \mathrm{C}$ and $5.0^{\circ} \mathrm{C}$, excretion increased, $47 \%$ at salinity $25,37 \%$ at salinity 30 and $13 \%$ at salinity 35 . 
Gondogeneia antártica - oxygen consumption

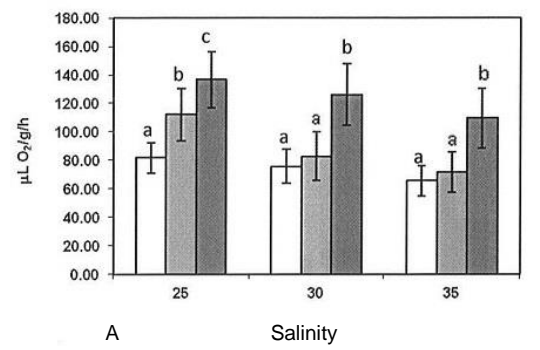

Gondogeneia antártica - oxygen consumption

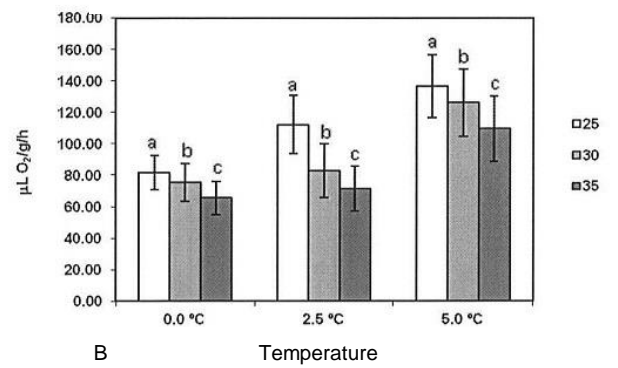

Fig. 1. Mean $( \pm \mathrm{SD})$ oxygen consumption rate $\left(\mu \mathrm{LO}_{2} / \mathrm{g}\right.$.h $)$ of Gondogeneia antarctica; a - as function of temperature, at different salinities; $\mathbf{b}$ - as function of salinity, at different temperatures. Different letters indicates significant differences between means of each group.

Gondogeneia antártica - Ammonia excretion

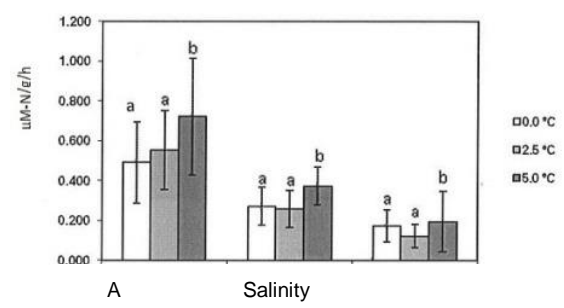

Gondogeneia antártica - Ammonia excretion

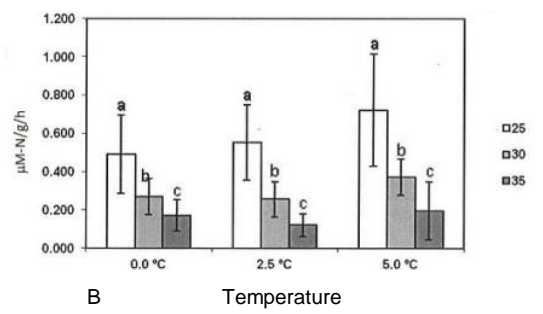

Fig. 2. Mean $( \pm$ SD) of ammonia excretion rate $(\mu \mathrm{M}-\mathrm{N} / \mathrm{g} . \mathrm{h})$ of Gondogeneia antarctica; $\mathbf{A}$ - as function of temperature, at different salinities; B - as function of salinity, at different temperatures. Different letters indicates significant differences between means of each group.
Table 1. O:N rates calculated from the means of oxygen consumption rates and ammonia excretion of Gondogeneia antarctica acclimated to different conditions of temperature (temp.) and salinity.

\begin{tabular}{cccc}
\hline \hline \multicolumn{4}{c}{ O:N } \\
\hline Temp./Salinity & 25 & 30 & 35 \\
$0.0^{\circ} \mathrm{C}$ & 11.57 & 19.37 & 26.46 \\
$2.5^{\circ} \mathrm{C}$ & 14.08 & 22.38 & 40.94 \\
$5.0^{\circ} \mathrm{C}$ & 13.13 & 23.51 & 39.08 \\
\hline
\end{tabular}

The means $( \pm$ SD) of ammonia excretion rates of amphipods as a function of salinities at different temperatures (Fig. 2b) indicate that ammonia excretion decreased significantly with increasing salinity, at the three temperatures studied. At $0.0^{\circ} \mathrm{C}$, $2.5^{\circ} \mathrm{C}$ and $5.0^{\circ} \mathrm{C}$ excretion decreased, respectively, $185 \%, 357 \%$ and $272 \%$ between salinities 25 and 35 .

The O:N ratio for $G$. antarctica varied from 11.57 to 40.94 (Table 1). Regarding the temperature effects at each salinity, the $\mathrm{O}: \mathrm{N}$ ratios increased between $0^{\circ} \mathrm{C}$ and $2.5^{\circ} \mathrm{C}$, and maintained similar values at $2.5^{\circ} \mathrm{C}$ and $5^{\circ} \mathrm{C}$. At salinity 25 , the ratios were under 16; at salinity 30 the ratio varied from 19.37 to 23.51 ; and at salinity 35 the ratio varied from 26.46 to 40.94 .

\section{DisCUSSION}

Antarctic ectotherms have developed complex mechanisms to adjust physiological processes to stable water temperatures and salinity, mainly with a view to energy saving (CLARKE et al., 2007; ROGERS et al., 2007), in spite of considerable interespecific differences between them (CHAPELLE; PECK, 1995; GOMES et al., 1995). Our data seem to fit these environmental aspects of stability. As expected, both oxygen consumption and ammonia excretion of $G$. antarctica increased with increasing temperature and decreased with increasing salinity but these changes were notably dissimilar. When examining the data of individuals of $G$. antarctica acclimated to salinities 30 and 35 - that could be considered as close to the usual, the metabolic rates at $0^{\circ} \mathrm{C}$ and $2.5^{\circ} \mathrm{C}$ were similar. At these salinities, a significant increase in metabolism was evident only when comparing the consumptions at $0^{\circ} \mathrm{C}$ and at $2.5^{\circ} \mathrm{C}$ to that at $5^{\circ} \mathrm{C}$. Studies with Antarctic ectotherms also revealed that when temperature variations are closer to the seasonal range, physiological processes remain at similar rates but, when temperature is above the usual, unexpected increases may occur (JOHNSTON et al., 1991; PECK, 2002; OBERMÜLLER et al., 2007). Stability also helps to explain why metabolic rates at salinity 25 always increased significantly with increasing temperature, even when the range was between $0^{\circ} \mathrm{C}$ to $2.5^{\circ} \mathrm{C}$. At salinity 25 mechanisms of metabolic thermal compensation seem not to operate properly. It is known that salinity variations can produce significant changes in the energy 
demands of polar and non-polar ectotherms, including parasites (MÖLLER, 1978; ALLAN et al., 2006; FILIPPOV, 2006). Species adapted to broad variations of environmental factors, such as the temperate shrimp Palaemon peringuery, for instance, did not show any significant differences in oxygen consumption when data measured at the same temperature over a salinity range of 15 to 35 were compared (ALLAN et al., 2006). Antarctic ectotherms may present distinct adaptive ability depending on the species (WILSON et al., 2002; JANECKI et al., 2010; EVANS et al., 2012) and their respective habitats. Coastal water Antarctic ectotherms, however, seem to have a low capacity to survive during long periods at temperatures higher than the environmental average, even if they are able to tolerate this same temperature during a certain period of time (PÖRTNER et al., 2001; PECK, 2005; TOMANEK, 2008). Little is known about the joint effects of salinity and temperature on polar organisms and this study is a contribution to fill this gap.

The increase of ammonia excretion of $G$. antarctica at lower salinity and the increase with increasing temperature are probably related, among other things, to processes such as ionic exchanges, osmoregulation and the substrate used for metabolism. These processes are partially responsible to the increase in energy demand. At higher temperatures and lower salinity the animals are subjected to greater metabolic stress. The same situation has been detected for other species of ectotherms such as amphipods (AARSET; AUNAAS, 1990; NORMANT; LAMPRECHT, 2006) and fish (ROCHA et al., 2005). At higher salinities the lower rates of ammonia excretion are to be expected, probably as a consequence of reduced metabolism of amino acids and their retention as free amino acids in tissues related to osmoregulation (FRICK; WRIGHT, 2002; ROCHA et al., 2005).

The explanation for the Antarctic ectotherms' susceptibility to temperature and salinity variations is not simple. We do not have data on how long $G$. antarctica would survive at $5^{\circ} \mathrm{C}$ under the stressing conditions of enhanced energy demand. Nevertheless, some authors consider that the narrow limits of metabolic compensation could be related to selective pressures to fix a minimal basal metabolism to reserve enough energy to maintain the scope for activity of an organism living in cold waters with alternation of periods of plentiful and scarce food resources (PÖRTNER, 2006; PÖRTNER; KNUST, 2007). In fact, studies have demonstrated that the death of Antarctic ecthoterms after a long lasting rise in temperature is not only due to the effects of temperature itself over molecular kinetics. Probably, the main constraint is that accelerated metabolism demands an oxygen level that cannot be supplied to tissues due to the organism's inability to transport and distribute oxygen at low cost, proton leakage at mitochondria during ATP production and the low anaerobic capacities of organisms (PÖRTNER, 2002; 2006). In this case tissue hypoxia can occur.

Distinct mechanisms can be employed to maintain the internal homeostasis and the adequate level of energy expenditure, varying from behavioral changes to shifts of distinct metabolic pathways (ECHEVARRÉA et al., 1993; ROCHA et al., 2001). $\mathrm{O}: \mathrm{N}$ values indicate the nature of the substrate that is being used to meet energy demand. Values up to 16 indicate a protein-dependent metabolism; values between 16 and 60 indicate dependence on different proportions of proteins and lipids; values over 60 indicate a fat-dependent metabolism (MAYZAUD; CONOVER, 1988). Our data suggest a metabolism depending mainly on proteins shifting to a dependence on a mixture of proteins and lipids. The O:N ratio increased with increasing salinity at every temperature studied. So data indicated that protein-based metabolism made an increasing contribution of lipids with increases in temperature (from $0^{\circ} \mathrm{C}$ to $2.5^{\circ} \mathrm{C}$ ) and salinity. O:N values suggest that the metabolism of $G$. antarctica is mainly dependent on proteins at salinity 25 , increasing the proportion of lipids as salinity increases. At any salinity, the metabolism at $0^{\circ} \mathrm{C}$ is dependent on a higher proportion of proteins than at the other temperatures. These data are complex but they are clearly related to metabolic pathways. Probably, as energy demand changes with temperature and salinity, the shifts of substrate are part of the mechanisms used to supply energy efficiently under the specific conditions.

Ecophysiological data obtained thus far from Antarctic ectotherms populations indicate that stenothermic animals are highly sensitive to warming (PÖRTNER et al., 2006). The results of this study have demonstrated that the capacity of $G$. antarctica to compensate their metabolic rates seems to be limited. The stenohaline amphipod is proved to alter its energetic demand, and lower salinities as well as higher temperatures can greatly affect the homeostasis of the organism when acting together with other physical changes in the environment. Concomitant changes in other factors such as salinity, $\mathrm{pH}$ and oxygen content, among others, would make temperature effects even harder to compensate for. Further studies on the mechanisms of thermostability are called for to enable one to draw trustworthy inferences as to the ability of these organisms to face global changes.

\section{AcKNOWLEDGMENTS}

We wish to thank the "Programa Antártico Brasileiro" (CNPq-PROANTAR) for its financial support, the "Secretaria da Comissão Interministerial 
para os Recursos do Mar" (SECIRM) and the "Instituto Oceanográfico da Universidade de São Paulo" (IOUSP) for their logistic support. We are also grateful to the Brazilian Antarctic Station "Comandante Ferraz" for their assistance and hospitality.

\section{REFERENCES}

AARSET, A. V.; AUNAAS, T. Effects of osmotic stress on oxygen consumption and ammonia excretion of the Arctic sympagic amphipod Gammarus wilkitzkii. Mar. Ecol.: Prog. Ser., v. 58, p. 217-224, 1990.

ALLAN, E. L.; FRONEMAN, P. W.; HODGSON, A. N. Effects of temperature and salinity on the standard metabolic rate (SMR) of the caridean shrimp Palaemon peringueyi. J. Exp. Mar. Biol. Ecol., v. 337, n. 1, p. 103-108, 2006.

ARNTZ, W. E.; BREY, T.; GALLARDO, V. A. Antarctic zoobenthos. Oceanogr. Mar. Biol., v. 32, p. 241-304, 1994.

CHAPELLE, G.; PECK, L. S. The influence of acclimation and substratum on the metabolism of the Antarctic amphipods Waldeckia obesa (Chevreux, 1905) and Bovallia gigantea (Pfeffer, 1888). Polar Biol., v. 15, n. 3, p. 225-232, 1995.

CLARKE, A.; JOHNSTON, N. M.; MURPHY, E. J.; ROGERS, A. D. Introduction. Antarctic ecology from genes to ecosystems: the impact of climate change and the importance of scale. Philos. Trans. R. Soc. London, Ser. B, v. 362, n. 1477, p. 5-9, 2007.

DE BROYER, C.; JAZDZEWSKI, K. Contribution to the marine biodiversity inventory: a checklist of the Amphipoda (Crustacea) of the Southern Ocean. Brussels: Institut Royal des Sciences Naturalles de Belgique, 1993. 154 p. (Documents de travail; v. 73).

DUARTE, W. E.; MORENO, C. A. The specialized diet of Harpagifer bispinis. Hydrobiologia, v. 80, n. 3, p. 241250, 1981.

ECHEVARRÉA， G.; ZARAUZ, N.; LÓPEZ-RUIZ, J.; ZAMORA, S. Study of nitrogen excretion in the gilthead seabream (Sparus aurata L.): influence of nutritional state. Comp. Biochem. Physiol., Part A: Physiol., v. 105, n. 1, p. 17-19, 1993.

EICKEN, H. The role of sea ice in structuring Antarctic ecosystems. Polar Biol., v. 12, n. 1, p. 3-13, 1992.

EVANS, C. W.; WILlIAMS, D. E.; VACCHI, M.; BRIMBLE, M. A.; DeVRIES, A. L. Metabolic and behavioural adaptations during early development of the Antarctic silverfish, Pleuragramma antarcticum. Polar Biol., v. 35, n. 6, p. 891-898, 2012.

FILIPPOV, A. A. Adaptability of the amphipod Pontoporeia affinis (Crustacea, Amphipoda) to salinity changes. Russ. J. Mar. Biol., v. 32, n. 3, p. 198-200, 2006.

FOX, H. M.; WINGFIELD, C. A. A portable apparatus for the determination of oxygen dissolved in a small volume of water. J. Exp. Biol., v. 15, p. 437-445, 1938.

FRICK, N. T.; WRIGHT, P. A. Nitrogen metabolism and excretion in the mangrove killifish Rivulus marmoratus. I. The influence on environmental salinity and external ammonia. J. Exp. Biol., v. 205, pt. 1, p. 79-89, 2002.

GOMES, V.; PHAN, V. N.; PASSOS, M. J. A. C. R. Estudo do metabolismo de rotina e da excreção de amônia do anfípoda antártico Waldeckia obesa em duas temperaturas distintas. Bol. Inst. Oceanogr., v. 43, n. 2, p. 129-139, 1995.

GOMES, V.; PASSOS, M. J. A. C. R.; LEME, N. M. P.; SANTOS, T. C. A.; CAMPOS, D. Y. F.; HASUE, F. M.; PHAN, V. N. Photo-induced toxicity of anthracene in the Antarctic shallow water amphipod, Gondogeneia antarctica. Polar Biol., v. 32, n. 7, p. 1009-1021, 2009.

HEMPEL, G. Antarctic ecosystems changes and conservation: review of the Fifth Symposium on Antarctic Biology. In: KERRY, K. R.; HEMPEL, G. (Eds.). Antarctic ecosystems ecological change and conservation. Berlin: Springer-Verlag, 1990. p. $407-$ 414. [Symposium on Antarctic Biology (Scar), 5, Hobart, Australia, 1988].

JANECKI, T.; KIDAWA, A.; POTOCKA, M. The effects of temperature and salinity on vital biological functions of the Antarctic crustacean Serolis polita. Polar Biol., v. 33, n. 8, p. 1013-1020, 2010.

JAZDZEWSKI, K.; DE BROYER, C.; PUDLARZ, M.; ZIELINSKI, D. Seasonal fluctuations of vagile benthos in the uppermost sublittoral of a maritime Antarctic fjord. Polar Biol., v. 24, n. 12, p. 910-917, 2001.

JAZDZESKI, K.; JURASZ, W.; KITTEL, W.; PRESLER, E.; PRESLER, P.; SICINSKI, J. Abundance and biomass estimates of the benthic fauna in Admiralty Bay, King George Island, South Shetland Islands. Polar Biol., v. 6, n. 1, p. 5-16, 1986.

JOHNSTON, I. A.; CLARKE, A.; WARD, P. Temperature and metabolic rate in sedentary fish from the Antarctic, North Sea and Indo-West Pacific Ocean. Mar. Biol., v. 109, n. 2, p. 191-195, 1991.

KOROLEFF, F. Direct determination of ammonia in natural waters as indophenol blue. 1970. In: GRASSHOFF, K.; KREMLING, K.; EHRHARDT, M. (Eds.). Methods of seawater analysis. Weinheim, New York: Wiley-VCH, 1999, p. 191-193.

MAYZAUD, P. Respiration and nitrogen excretion of zooplankton. II. Studies of the metabolic characteristics of starved animals. Mar. Biol., v. 21, n. 1, p. 19-28, 1973.

MAYZAUD, P.; CONOVER, R. J. O:N atomic ratios as a tool to describe zooplankton metabolism. Mar. Ecol.: Prog. Ser., v. 45, p. 289-302, 1988.

MÖLLER, $H$. The effects of salinity and temperature on the development and survival of fish parasites. J. Fish Biol., v. 12 , n. 4, p. 311-323, 1978.

MONTONE, R. C.; ALVAREZ, C. E.; BÍCEGO, M. C.; BRAGA, E. S.; BRITO, T. A. S.; CAMPOS, L. S.; FONTES, R. F. C.; CASTRO, B. M.; CORBISIER, T, N.; EVANGELISTA, H.; FRANCELINO, M.; GOMES, V.; ITO, R. G.; LAVRADO, H. P.; PAES LEME, N.; MAHIQUES, M. M.; MARTINS, C. C.; NAKAYAMA, C. R.; NGAN, P. V.; PELLIZARI, V. H.; PEREIRA, A. B.; PETTI, M. A. V.; SANDER, M.; SCHAEFER, C. E. G. R.; WEBER, R. R. Environmental assessment of Admiralty Bay, King George, Antarctica. In: VERDE, C.; DI PRISCO, G. (Eds.). Adaptation and evolution in marine environments, from pole to pole. Berlin: Heidelberg: Springer-Verlag, 2013. v. 2, p. 157-175.

NORMANT, M.; LAMPRECHT, I. Does scope for growth change as a result of salinity stress in the amphipod Gammarus oceanicus? J. Exp. Mar. Biol. Ecol., v. 334, n. 1, p. 158-163, 2006. 
OBERMÜLlER, B.; PUNTARULO, S.; ABELE, D. UVtolerance and instantaneous physiological stress responses of two Antarctic amphipod species Gondogeneia antarctica and Djerboa forcipes during exposure to UV radiation. Mar. Environ. Res., v. 64, n. 3, p. 267-285, 2007.

PECK, L. S. Ecophysiology of Antarctic marine ectotherms: limits to life. Polar Biol., v. 25, n. 1, p. 31-40, 2002.

PECK, L. S. Prospects for survival in the Southern Ocean: vulnerability of benthic species to temperature change. Antarct. Sci., v. 17, n. 4, p. 497-507, 2005.

PÖRTNER, H. O. Climate variations and the physiological basis of temperature dependent biogeography: systemic to molecular hierarchy of thermal tolerance in animals. Comp. Biochem. Physiol., Part A: Mol. Integr. Physiol., v. 132, n. 4, p. 739-761, 2002.

PÖRTNER, H. O. Climate-dependent evolution of Antarctic ectotherms: an integrative analysis. Deep Sea Res., Part II, v. 53, n. 8/10, p. 1071-1104, 2006. [EASIZ: Ecology of the Antarctic Sea Ice Zone; Ecology of the Antarctic Sea Ice Zone: Final Symposium].

PÖRTNER, H. O.; BENNETT, A. F.; BAZINOVIC, F.; CLARKE, A.; LARDIE, M. A.; LUCASSEN, M.; PELSTER, B.; SCHIEMER, F.; STILLMAN, J. H. Trade-offs in thermal adaptation: the need for a molecular to ecological integration. Physiol. Biochem. Zool., v. 79, n. 2, p. 295-313, 2006.

PÖRTNER, H. O.; BERDAL, B.; BLUST, R.; BRIX, O.; COLOSIMO, A.; DE WACHTER, B.; GIULIANI, A.; JOHANSEN, T.; FISCHER, T.; KNUST, R.; LANNIG, G.; NAEVDAL, G.; NEDENES, A.; NYHAMMER, G.; SARTORIS, F. J.; SERENDERO, I.; SIRABELLA, P.; THORKILDSEN, S.; ZAKHARTSEV, M. Climate induced temperature effects on growth performance, fecundity and recruitment in marine fish: developing hypothesis for cause and effect relationships in Atlantic cod (Gadus morhua) and common eelpout (Zoarces viviparus). Cont. Shelf Res., v. 21, n. 18/19, p. 19751997, 2001. [Review].

PÖRTNER, H. O.; KNUST, R. Climate change affects marine fishes through the oxygen limitation of thermal tolerance. Science, v. 315, n. 5808, p. 95-97, 2007.

PRUSZAK, Z. Currents circulation in the waters of Admiralty Bay (region of Arctowski Station on King George Island). Pol. Polar Res., v. 1, n. 1, p. 55-74, 1980.

RAKUSA-SUSZCZEWSKI, S. Environmental conditions and the functioning of Admiralty Bay (South Shetland Islands) as part of the near shore Antarctic ecosystem. Pol. Polar Res., v. 1, n. 1, p. 11-27, 1980.
RICHARDSON, M. G. The dietary composition of some Antarctic fish. Br. Antarct. Surv. Bull., v. 41/42, p. 113-120, 1975.

ROCHA, A. J. S.; GOMES, V.; PHAN, V. N.; PASSOS, M. J. A. C. R. Variações na demanda de energia metabólica de juvenis de Haemulon steindachneri (Perciformes, Haemulidae) em função da temperatura. Rev. Bras. Oceanogr., v. 49, n. 1/2, p. 87-97, 2001.

ROCHA, A. J. S.; GOMES, V.; PHAN, V. N.; PASSOS, M. J. A. C. R.; FURIA, R. R. Metabolic demand and growth of juveniles of Centropomus parallelus as function of salinity. J. Exp. Mar. Biol. Ecol., v. 316, n. 2, p. 157$165,2005$.

ROGERS, A. D.; MURPHY, E. J.; JOHNSTON, N. M.; CLARKE, A. Introduction. Antarctic ecology: from genes to ecosystems. Part 2. Evolution, diversity and functional ecology. Philos. Trans. R. Soc. London, Ser. B, v. 362, n. 1488, p. 2187-2189, 2007.

SZAFRANSKI, Z.; LIPSKI, M. Characteristics of water, temperature and salinity at Admiralty Bay (King George Island, South Shetland Islands, Antarctica) during the austral summer 1978/1979. Pol. Polar Res., v. 3, n. 1/2, p. 7-24, 1982.

TOMANEK, L. The importance of physiological limits in determining biogeographical range shifts due to global climate change: the heat-shock response. Physiol. Biochem. Zool., v. 81, n. 6, p. 709-717, 2008.

WEBER, R. R.; MONTONE, R. C. (Coords.). Rede-2: Gerenciamento ambiental na Baía do Almirantado, Ilha Rei George, Antártica. Relatório Final da Rede2. Brasília: Ministério do Meio Ambiente, CNPqPROANTAR, SECIRM, 2006. 261 p.

WHITE, M. G. Marine benthos. In: LAWS, R. M. (Ed.). Antarctic ecology. London: Academic Press, 1984. v. 2, p. 421-461.

WILSON, R. S.; KUCHEL, L. J.; FRANKLIN, C. E.; DAVISON, W. Turning up the heat on subzero fish: thermal dependence of sustained swimming in an Antarctic notothenioid. J. Therm. Biol., v. 27, n. 5, p. 381-386, 2002.

(Manuscript received 11 January 2013; revised 01 October 2013; accepted 02 November 2013) 